\title{
EFEKTIVITAS PROGRAM "TUKA TUKU PURBALINGGA" SEBAGAI MEDIA PEMASARAN UMKM DI KABUPATEN PURBALINGGA TAHUN 2019
}

\author{
Dicky Yuliawan'1), Erni Zuhriyati1) \\ 1) Program Studi Ilmu Pemerintahan, FISIPOL, Universitas Muhammadiyah \\ Yogyakarta, Indonesia
}

\begin{abstract}
Abstrak
Tujuan dari penelitian ini adalah untuk menganalisis efektifitas program Tuka Tuku Purbalingga sebagai media pemasaran UMKM di Kabupaten Purbalingga tahun 2019. Metode penelitian yang digunakan dalam penelitian ini adalah penelitian kualitatif deskriptif yang dilakukan pada tahun 2020. Adapun yang menjadi objek dalam penelitian ini yaitu sekertariat program Tuka Tuku Purbalingga, pelaku UMKM, dan masyarakat di Kabupaten Purbalingga. Pengumpulan data dilakukan dengan wawancara, dokumentasi dan observasi. Dalam pelaksanaan program Tuka Tuku berkaitan dengan (1) Ketepatan sasaran program Tuka Tuku Purbalingga sudah menyasar pelaku UMKM, namun perlu peningkatan dalam hal jumlah UMKM yang bergabung dalam program. (2) Sosialisasi program Tuka Tuku dapat disimpulkan bahwa sosialisasi dilakukan dengan strategi yang cukup baik, namun perlu ditingkatkan lagi dalam penyampian informasi program karena masih banyak masyarakat yang belum menerima informasi program Tuka Tuku secara keseluruhan dan belum dilakukan secara intens atau terus menrus. (3) Tujuan program Tuka Tuku dapat dirasakan manfaatnya oleh pelaku UMKM dan masyarakat, sehingga hasil dari pelaksanaan program Tuka Tuku sudah sesuai dengan tujuan yang direncanakan sebelumnya. (4) Pemantuan program sudah dilakukan terhadap pelaku UMKM yang bergabung dalam program terutama berkaitan dengan masalah dan hambatan yang dialami pelaku UMKM.
\end{abstract}

Kata Kunci: Efektivitas, Program Tuka Tuku, Purbalingga, UMKM

\begin{abstract}
The purpose of this study was to analyze the effectiveness of the Tuka Tuku Purbalingga program as a marketing medium for SMEs in Purbalingga Regency in 2019. The research method used in this study was a qualitative descriptive study conducted in 2020. The object of this research is the Tuka secretariat program. Tuku Purbalingga, MSME actors, and the community in Purbalingga Regency. Data collection was done by interview, documentation, and observation. The implementation of the Tuka Tuku program, is related to (1) The targeting of the Tuka Tuku Purbalingga program has targeted MSME actors, but it is necessary to increase the number of MSMEs joining the program. (2) The socialization of the Tuka Tuku program can be concluded that the socialization is carried out with a fairly good strategy, but it needs to be further improved in the delivery of program information because there are still many people who have not received information on the Tuka Tuku program as a whole and have not been carried out intensely or continuously. (3) The purpose of the Tuka Tuku program can be felt by MSME actors and the community so that the results of the implementation of the Tuka Tuku program are in accordance with the previously planned objectives. (4) Program monitoring has been
\end{abstract}


carried out on MSME actors who join the program, especially with regard to problems and obstacles experienced by MSME actors.

Keywords: Effectiveness, Tuka Tuku Program, Purbalingga, MSMEs

\section{PENDAHULUAN}

Usaha Mikro Kecil dan Menengah (UMKM) merupakan unit usaha yang sangat penting keberadaanya, mengingat UMKM memiliki peran strategis dalam pembangunan ekonomi nasional (Suci, 2017). Hal ini karena keberadaan UMKM dapat menyediakan dan menyerap banyak tenaga kerja sehingga dapat mengurangi masalah pengangguran dan kemiskinan, serta berperan dalam peningkatan pendapatan masyarakat, membantu mendorong pertumbuhan ekonomi sehingga terciptanya stabilitas nasional (Sudaryanto et al., 2013). Perkembangan UMKM yang semakin pesat di era saat ini menjadi tanggung jawab pemerintah untuk mengatur dan mengelola kegiatan tersebut. Pemerintah memiliki peran untuk memberikan fasilitas bagi pelaku UMKM untuk dapat berkembang, mencapai tujuan dan bersaing dengan produk pabrikan ataupun produk impor dari luar negeri (Putra, 2015).

Berdasarkan data dari Badan Pusat Statistik (BPS) Kabupaten Purbalingga pada sensus ekonomi tahun 2019, di Kabupaten Purbalingga terdapat 96.592 UMKM yang tersebar di 18 kecamatan. Jumlah terbanyak terdapat di Kecamatan Purbalingga dengan jumlah 9.555 UMKM, selanjutnya disusul oleh Kecamatan Mrebet dengan 7.930 UMKM dan Kecamatan Bukateja dengan jumlah 7.558 UMKM (BPS, 2019). Dari banyaknya UMKM di Kabupaten Purbalingga, masing-masing bergerak di berbagai sektor dengan memanfaatkan potensi daerah, mulai dari sektor pariwisata, kuliner, tekstil, sampai dengan kerajinan (Shadiq \& Njatrijani, 2016). Dari sektor kuliner, seperti produk Gula Kristal dan Abon Sapi yang sudah mulai bersaing dengan produk nasional bahkan sudah di ekspor ke beberapa negara di Asia Tenggara dan Eropa. Dari sektor kerajinan juga tak kalah mendominasi, seperti kerajianan produk kenalpot dan kerajinan anyaman sapu yang sudah bersaing hingga pasar internasional (Ryan Rachman, 2019). 
Dengan banyaknya UMKM yang tersebar di Kabupaten Purbalingga, Pemerintah Kabupaten Purbalingga berupaya untuk membuat program yang dapat membantu UMKM dalam mengembangkan, memajukan dan memasarkan produk-produk mereka. Upaya ini dimulai pada tahun 2017 dengan diluncurkannya program Bela Beli Purbalingga oleh Bupati Tasdi dengan tujuan untuk memberikan fasilitas dan meningkatkan daya saing pelaku UMKM di Kabupaten Purbalingga. Program Bela Beli Purbalingga pada saat itu dianggap menjadi program pemerintah yang pro kepada masyarakat kecil, khususnya pelaku UMKM di Kabupaten Purbalingga karena dianggap mampu meningkatkan perekonomian masyarakat (Muzaki, 2018). Melalui program ini, pemerintah daerah juga mewajibkan penggunaan terhadap produk-produk UMKM dalam setiap kegiatan yang dilakukan oleh seluruh organisasi perangkat daerah, mulai dari tingkat kabupaten, tingkat kecamatan hingga tingkat desa. Program ini berjalan selama dua tahun dan digantikan dengan program baru, yaitu program Tuka Tuku Purbalingga.

Program Tuka Tuku Purbalingga yang diluncurkan pada Agustus 2019 berjalan setelah banyaknya kegagalan marketplace baik di dalam daerah itu sendiri maupun daerah-daerah lain. Kegagalan tersebut tidak lantas menghalangi dan membuat pesimis Pemerintah Kabupaten Purbalingga dalam menjalankan program Tuka Tuku. Komitmen pemerintah dibuktikan dengan nilai omset yang diperoleh mencapai Rp 90,9 juta pada Desember 2019 (Murdaningsih, 2020). Program Tuka Tuku ini juga sebagai dorongan yang diberikan oleh Pemerintah Kabupaten Purbalingga untuk memasarkan produk UMKM yang semakin berkembang melalui pemberian fasilitas pemasaran yang ideal dengan harapan mampu memberikan peningkatan pada perekonomian di Kabupaten Purbalingga. Progam Tuka Tuku Purbalingga merupakan program yang diluncurkan oleh Pemerintah Kabupaten Purbalingga dengan tujuan yang sama dengan program sebelumnya, yaitu untuk memberikan fasilitas bagi pelaku UMKM dalam memperluas pemasaran produk, baik secara offline maupun online (Andika, 2019). Pemasaran secara online dilakukan dengan menyediakan marketplace atau platform belanja online yang telah bekerjasama dengan 
perusahaan e-commerce Indonesia yaitu PT Bukalapak (Wulandari \& Putri, 2020). Selain kolaborasi dengan perusahan e-commerce terkemuka, Program Tuka Tuku Purbalingga juga melakukan kolaborasi dengan perusahaan swasta lainya seperti Indomaret dan Alfamart guna menunjang pemasaran produk-produk UMKM secara online maupun offline. Kerjasama yang dilakukan juga sebagai bentuk kolaborasi antara pemerintah, swasta dan masyarakat dalam hal ini pelaku UMKM dalam peningkatan kualitas dan kuantitas penjualan produk-produk UMKM di Kabuparen Purbalingga. Diliriknya program Tuka Tuku Purbalingga oleh Kementerian Desa sebagai pilot projek percontohan pertama, menjadikan program ini menarik untuk diteliti.

Jika pada penelitian sebelumnya banyak yang berfokus pada pemanfaatan media online atau e-commerce dalam pengembangan dan pemberdayaan UMKM seperti penelitian oleh (Irawan et al., 2020) tentang pemberdayaan UKM melalui implementasi e-commerce di Kelurahan Tlogomas, penelitian yang dilakukan oleh (Amelia et al., 2017) terkait EUMKM sebagai aplikasi pemasaran produk UMKM berbasis android dan penelitian oleh (Susanti, 2017) tentang pemanfaatan e-commerce untuk mendukung UMKM dalam pemasaran, maka penelitian ini akan lebih berfokus pada efektifitas program Tuka Tuku Purbalingga yang juga berfungsi sebagai media pemasaran produk-produk UMKM di Kabupaten Purbalingga, dimana untuk mengukur efektivitas program tersebut akan digunakan beberapa indikator seperti ketepatan sasaran program, sosialisasi program, tujuan program dan pemantauan program.

\section{METODE PENELITIAN}

Metode dalam penelitian ini menggunakan pendekatan metode kualitatif deskriptif. Penelitian kualitatif digunakan untuk menemukan sekaligus mengumpulkan jawaban dari narasumber atau reponden untuk menjawab permasalahan-permasalahan yang sedang diteliti (Subandi, 2011). Kemudian data-data yang telah diperoleh, dideskripsikan untuk memperjelas jawaban atas permasalahan agar mempermudah pembaca dalam memahami hasil penelitian (Gumilang, 2016). Diri peneliti sebagai 
isntrumen kunci dalam penelitian ini, karena penelitilah yang menetapkan fokus penelitian, memilih informan sebagai sumber data, melakukan pengumpulan data, menilai kualitas data, menganalisis data, menafsirkan data, dan membuat kesimpulan atas temuannya.

Dalam penelitian ini menggunakan teknik pengumpulan data wawancara, dokumentasi, dan observasi. Wawancara merupakan teknik pengumpulan data dengan cara tanya jawab atau wawancara secara langsung dengan tujuan untuk memperoleh informasi yang lebih jelas tentang objek yang diteliti ( $\&$ \& , 2002). Dokumentasi diartikan sebagai informasi dengan catatan, baik yang berasal dari sebuah intansi lembaga maupun perorangan mengenai peristiwa atau kegiatan dalam keadaan sosial yang terkait dengan fokus penelitian, yang dimana sumber dokumen tersebut berguna dan membantu dalam penelitian kualitatif (Yusuf, 2014) seperti foto-foto, laporan, jurnal, dan website. Sedangkan observasi merupakan kegiatan manusia yang menggunakan panca indera untuk mengamati suatu hal. Penggunaan teknik observasi juga dapat mengeksplorasi dengan memberikan gambaran jelas tentang permasalahan dan petunjuk pemecahannya (Hasanah, 2017).

\section{PEMBAHASAN}

Menurut Supriyono (2000), efektivitas diartikan sebagai suatu hubungan antara keluaran dengan tujuan atau sasaran yang hendak dicapai, yang mana semakin besar kontribusi dalam mencapai suatu tujuan maka semakin efektif pula hasilnya. Dengan kata lain, efektivitas berfokus pada hasil (outcome), suatu kegiatan atau program akan dianggap efektif apabila output akhir yang diperoleh dapat memenuhi atau sesuai dengan tujuan yang diharapkan. Efektivitas dapat pula menunjukkan seberapa jauh tujuan yang telah ditetapkan atau ditargetkan sebelumnya dapat tercapai, baik itu dari segi kuantitas, kualitas ataupun waktu pelaksanaannya (Indrayani \& Niswah, 2017).

Dalam pembahasan ini, dilakukan analisis terhadap efektifitas program Tuka Tuku Purbalingga sebagai media pemasaran UMKM yang ada di Kabupaten Purbalingga dengan menggunakan indikator efektifitas 
menurut Budiani dalam (Khadafi \& Mutiarin, 2017) yang terdiri atas ketepatan sasaran program, sosialisasi program, tujuan program dan pemantauan program.

\section{Ketepatan Sasaran Program pada Media Pemasaran}

Sasaran program merupakan target yang disasar atau dituju dari dibuatnya suatu program. Dalam hal ini, yang menjadi sasaran dari dibuatnya program Tuka Tuku Purbalingga yaitu UMKM yang ada di Kabupaten Purbalingga agar para pelaku UMKM dapat memasarkan produknya lebih luas lagi, mengingat UMKM di Kabupaten Purbalingga yang cukup banyak jumlahnya. Seperti yang disampaikan oleh manajer program Tuka Tuku Purbalingga yaitu Bapak Dimas dalam wawancaranya:

"Program Tuka Tuku Purbalingga ini sasarannya pelaku UMKM di Kabupaten Purbalingga, dan sampai saat ini menurut saya sudah cukup tepat sasaran karena program ini cukup bagus sebagai wadah bagi pelaku UMKM di Kabupaten Purbalingga dengan menjaring pelaku UMKM yang telah memiliki kualitas yang bagus dan produk-produk UMKM bisa memiliki standar nasional."

Menurut manajer program Tuka Tuku Purbalingga, program tersebut sudah cukup tepat menyasar UMKM di Kabupaten Purbalingga, dan dapat dimanfaatkan sebagai wadah atau media pemasaran untuk pelaku-pelaku UMKM. Selain itu, Ibu Yelfi sebagai pemilik usaha Marisa Food juga menyatakan hal yang sama:

"Dalam ketepatan sasaran program Tuka Tuku telah berjalan sesuai dan tepat sasaran karena setelah bergabung dengan program Tuka Tuku mampu membantu meningkatkan omset bagi produsen."

Dari wawancara tersebut, ketepatan sasaran juga dirasakan oleh salah pemilik usaha yang bergabung dengan program Tuka Tuku Purbalingga, dimana beliau merasa terbantu dan merasakan manfaat dari adanya program tersebut terutama dalam hal pemasaran produk, karena produk-produk UMKM yang telah bergabung program Tuka Tuku menjadi semakin dikenal luas oleh masyarakat. Selain itu, untuk melihat ketepatan sasaran dari program Tuka Tuku Purbalingga, dilakukan pula wawancara dengan masyarakat yang telah menggunakan Program Tuka Tuku Purbalingga yaitu Ibu Nuri Wahyuni:

"Program Tuka Tuku Purbalingga merupakan program yang bagus, terutama di era digital seperti sekarang ini. Menurut saya, terkait ketepatan sasaran 
program Tuka Tuka sudah tepat sasaran, karena sudah banyak produkproduk dari pelaku UMKM yang dikenal masyarakat secara luas dan tersedia di marketplace dan mudah diakses oleh masyarakat."

Berdasarkan wawancara dengan masyarakat yang telah menggunakan dan mengakses marketplace Tuka Tuku Purbalingga terkait ketepapan sasaran pada media pemasaran online, program Tuka Tuku Purbalingga sudah sesuai dan tepat sasaran, karena masyarakat telah banyak menerima manfaat dengan adanya program Tuka Tuku Purbalingga. Berdasarkan pada hasil wawancara, secara keseluruhan program Tuka Tuku Purbalingga dapat disimpulkan bahwa program Tuka Tuku Purbalingga telah tepat sasaran karena dapat memberikan manfaat bagi pelaku UMKM dengan adanya peningkatan penjualan produk setelah bergabung dengan program Tuka Tuku. Selain memberi dampak baik pada pelaku UMKM di Kabupaten Purbalingga, program Tuka Tuku juga memberikan manfaat bagi masyarakat dengan mendapatkan kemudahan untuk membeli dan mengenal produk-produk lokal Kabupaten Purbalingga.

Ketepatan sasaran program Tuka Tuku Purbalingga juga dibuktikan dengan adanya peningkatan omset pada penjualan produk-produk UMKM. Sejak menjalin kerjasama dengan perusahaan Bukalapak, produk-produk UMKM yang telah bergabung di program Tuka Tuku mengalami peningkatan penjualan cukup banyak, terhitung pada tanggal 31 Agustus 2019 sejak penandatanganan kerjasama Pemerintah Purbalingga dengan perusahaan e-commerce Bukalapak hingga bulan Desember 2019, program Tuka Tuku mampu memperoleh penjualan produk-produk UMKM kurang lebih mencapai angka 90 juta. Peningkatan penjualan produk UMKM selama empat bulan setelah bekerjasama dengan Bukalapak lebih jelasnya seperti laporan transaksi seperti dibawah ini: 
Tabel 1. Penjualan UMKM melalui Program Tuka Tuku

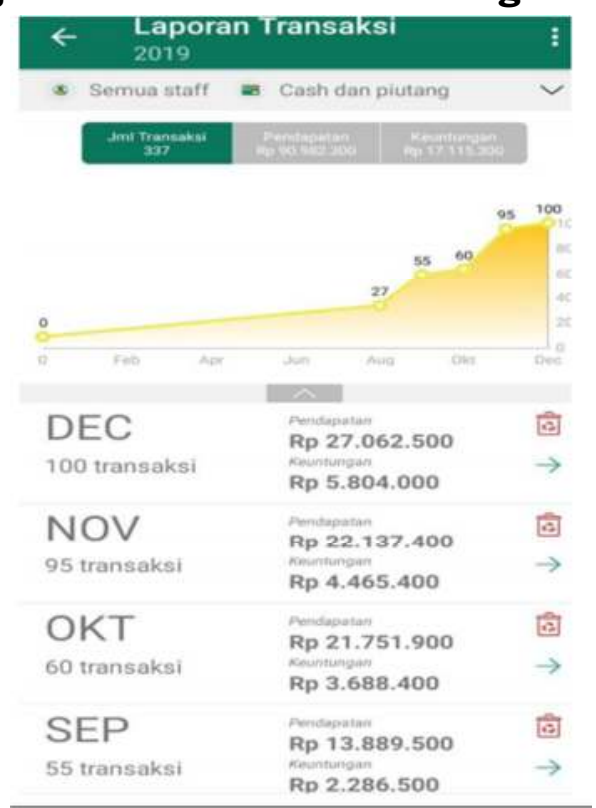

Sumber: Data Peneliti

Dari laporan penjualan produk-produk UMKM di Kabupaten Purbalingga melalui program Tuka Tuku, dapat dilihat bawah setiap bulannya mengalami peningkatan dengan omset yang mencapai 90 juta. Jika dilihat dari peningkatan pendapatan pelaku UMKM yang telah menjadi mitra program Tuka Tuku memang telah menunjukan adanya ketepatan, akan tetapi jika dinilai dari jumlah pelaku UMKM yang menjadi mitra Tuka Tuku dengan jumlah sebanyak 22 pelaku UMKM dari total UMKM keseluruhan Kabupaten Purbalingga sebanyak 96.592 dan yang sudah menjadi binaan oleh Dinas Koprasi dan Usaha kecil Menengah sebanyak 1.528 pelaku UMKM, maka perlu adanya peningkatan pendampingan dari pemerintah kepada pelaku UMKM.

Syarat utama bagi pelaku UMKM yang ingin menjadi mitra Tuka Tuku Purbalingga yaitu wajib memiliki izin PIRT, dan belum semua pelaku UMKM memiliki kemampuan untuk memperoleh izin tersebut, terutama UMKM yang masih dalam proses perkembangan atau UMKM yang masih kecil. Pendampingan perlu dilakukan guna mewujudkan ketepatan sasaran bagi program Tuka Tuku, misalnya dengan dilakukan pendampingan terlebih dahulu kepada Pelaku UMKM yang telah menjadi binaan dari Dinas Koprasi dan Usaha Kecil Menegah yang belum memiliki surat PIRT. Dengan pendampingan yang baik dan benar maka akan dapat meningkatkan 
jumlah pelaku UMKM yang memiliki PIRT, sehingga akan menambah pelaku UMKM yang mendaftar menjadi mitra Tuka Tuku Purbalingga, dengan lebih banyaknya Pelaku UMKM yang menjadi Mitra Tuka Tuku maka akan lebih banyak Pelaku UMKM yang terbantu melalui program Tuka Tuku Purbalingga tersebut.

\section{Sosialisasi Program pada Media Pemasaran}

Sosialisasi program pada media pemasaran online adalah rangkaian dari proses dalam menyampaikan informasi kepada msayarakat terkait program yang akan dilakukan. Tahap sosialisasi program merupakan proses komunikasi yang dibangun untuk memberikan informasi terkait program-program sampai dengan saran program. Tahap sosialisasi perlu dilakukan secara baik dan benar sehingga informasi dapat dengan mudah diterima oleh sasaran program, karena keberhasilan suatu program sangat dipengaruhi baik tidaknya dalam pelaksanaan sosialisasi.

Program Tuka Tuku Purbalingga melakukan tahapan sosialisasi kepada masyarakat dan tentunya pelaku UMKM yang ada di Kabupaten Purbalingga. Sosialisasi program Tuka Tuku Purbalingga dilakukan secara langsung dan tidak langsung. Pelaku UMKM Kabupaten Purbalingga yang menerima sosialisasi program Tuka Tuku secara langsung merupakan Pelaku UMKM yang telah menjadi binaan Dinas Koprasi dan UMKM Kabupaten Purbalingga, jumlah keseluruhan pelaku yang telah mendapatkan sosialisasi sebanyak 1.528 UMKM, sedangkan sosialisasi kepada masyarakat masih dilakukan secara tidak langsung yaitu melalui media sosial dan juga pemasangan spanduk di beberapa lokasi di Kabupaten Purbalingga. Seperti yang disampaikan oleh manajer program Tuka Tuku Purbalingga yaitu Bapak Dimas dalam wawancaranya:

"Terkait sosialisai program Tuka Tuku Purbalingga kepada pelaku UMKM sudah dilakukan secara langsung oleh pemerintah melalui forum binaan pelaku UMKM di Kabupaten Purbalingga. Sedangkan sosialisasi ke masyarakat dilakukan secara tidak langsung melalui media sosial dan spanduk-spanduk, dan saya rasa sosialisasi yang dilakukan sudah cukup baik, meskipun memang perlu ditingkatkan lagi karena masih banyak masyarakat di Kabupaten Purbalingga yang belum mengenal produk-produk UMKM dan program Tuka Tuku." 
Berdasarkan wawancara dari manajer program Tuka Tuku Purbalingga dapat disimpulkan bahwa program Tuka Tuku telah melakukan kegiatan sosialisai namun perlu ditingkatkan lagi karena masih cukup banyak masyarakat yang belum mengenal program Tuka Tuku dan produk-produk UMKM. Hal ini sejalan dengan apa yang disampaikan oleh Bapak Amil sebagai pemilik usaha makanan Nasi Jontor yang belum bergabung dalam program Tuka Tuku Purbalingga:

"Saya pernah mendengar bahwa ada program Tuka Tuku, tetapi belum pernah menerima sosialisasi dari program tersebut dan saya juga tidak aktif di media sosial, sehingga ketinggalan berita terkait program tersebut."

Dari wawancara tersebut, terlihat bahwa sosialisasi sudah dilakukan tetapi belum menyeluruh, sehingga belum semua pelaku UMKM mengetahui keberadaan ataupun cara bergabung dengan program tersebut. Sedangkan menurut Ibu Yelfi sebagai pemilik usaha Marisa Food yang sudah bergabung dengan program Tuka Tuku Purbalingga:

"Sosialisasi Program Tuka Tuku sudah cukup baik, apalagi sekarang lebih banyak dilakukan secara online sehingga setiap pelaku UMKM seharusnya tau adanya program, namun memang perlu dilakukan secara lebih aktif, berkala dan menyeluruh lagi, jadi semuanya bisa tahu."

Narasumber menyebutkan bahwa sosialisasi yang dilakukan sudah cukup baik, terbukti dengan terjalinnya hubungan yang baik antara pengelola program Tuka Tuku dan pelaku UMKM. Penyampaian informasi juga dilakukan secara terbuka terutama di media online yang juga menjadi bukti berjalannya sosialisasi program Tuka Tuku, tetapi perlu adanya peningkatan sosialisasi secara aktif, berkala dan lebih menyeluruh agar lebih banyak menjaring UMKM di berbagai wilayah di Kabupaten Purbalingga. Sebagai masyarakat yang telah menggunakan Tuka Tuku, Ibu Nuri Wahyuni menyampaikan bahwa:

"Sosialisasi program yang dilakukan sudah cukup baik dilakukan di media sosial seperti instagram dan facebook, karena memang saya aktif di media sosial, jadi lebih jelas, namun menurut saya, sosialisasi program secara langsung juga perlu ditingkatkan kembali sehingga semua lapisan masyarakat paham akan program tersebut."

Berdasarkan hasil wawancara tersebut, program Tuka Tuku dalam melaksanakan sosialisasi sudah dilakukan dengan cukup baik, namun perlu ditingkatkan lagi agar lebih banyak masyarakat yang paham dan 
mengerti terkait program Tuka Tuku Purbalingga. Dari hasil wawancara kepada seluruh narasumber dapat disimpulkan bahwa sosialisasi program Tuka Tuku Purbalingga memang sudah dilakukan dengan strategi yang baik, namun perlu ditingkatkan lagi dalam penyampaian informasi terkait program Tuka Tuku ini. Sosialisasi secara online perlu ditingkatkan terutama dengan melakukan kerjasama dengan media-media online yang memiliki pengikut yang cukup banyak sehingga dapat lebih menarik perhatian masyarakat. Selain itu, sosialisasi secara offline juga perlu ditingkatkan karena masih banyak masyarakat di Kabupaten Purbalingga yang membutuhkan penyampaian informasi terkait program Tuka Tuku.

\section{Tujuan Program pada Media Pemasaran}

Tujuan dapat diartikan sebagai pedoman dalam mencapai keberhasilan sebuah program, dan tujuan menjadi faktor yang penting untuk menentukan efektifitas program, yaitu sejauh mana kesesuaian antara hasil pelaksanaan program yang telah dicapai dengan tujuan program yang telah direncanakan sebelumnya. Tujuan dari program Tuka Tuku disampaikan oleh Bapak Dimas sebagai manajer program Tuka Tuku Purbalingga:

"Tujuan dari program Tuka Tuku Purbalingga pada intinya pemerintah ingin membantu pelaku UMKM dalam pemasaran produk. Pemerintah melakukan pembukaan pasar seluas luasnya bagi produk-produk UMKM guna membantu dalam pemasaran sehingga produk UMKM mampu menembus pasar yang sebelumnya sudah pemerintah sediakan."

Dari wawancara tersebut, dapat dikatakan bahwa program Tuka Tuku ini memiliki tujuan yang baik, dimana pemerintah berupaya untuk membantuk masyarakat dalam hal ini pelaku UMKM untuk memasarkan produknya secara lebih luas lagi. Dari tujuan tersebut, kemudian dilakukan wawancara dengan pemilik usaha yang sudah bergabung dalam program Tuka Tuku untuk menilai kesesuaian tujuan dengan hasil atau manfaat yang mereka rasakan. Wawancara dilakukan dengan Ibu Yelfi sebagai pemilik usaha Marisa Food:

"Tujuan program sudah sesuai kalau menurut saya, karena sudah dilakukan pemasaran oleh program Tuka Tuku secara lebih luas, selain itu adanya pelatihan dan pemberian masukan untuk meningkatkan branding atau kemasan juga membantu kami untuk meningkatkan kualitas produk. Selain 
itu adanya peningkatan penjualan pelaku UMKM juga menjadi bukti berjalanya program Tuka Tuku."

Berdasarkan pada hasil wawancara tersebut, dapat dikatakan bahwa hasil dari pelaksanaan program Tuka Tuku sesuai dengan tujuan dibuatnya program tersebut, karena pelaku UMKM merasakan hasil dan manfaat program tersebut, terbukti dengan pemasaran produk yang semakin meluas dan peningkatan kualitas produk melalui peningkatan kemasan dan branding produk. Selain tujuan Tuka Tuku yang sudah dapat dirasakan oleh pelaku UMKM, tujuan dari pelaksanaan program tersebut juga dirasakan oleh masyarakat sebagai pengguna program Tuka Tuku, yaitu Ibu Nuri Wahyuni:

"Untuk tujuanya menurut saya sudah bagus serta dapat membantu pelaku UMKM dan masyarakat, karena sebagai pengguna saya sudah cukup merasakan manfaat dari program ini, yaitu dengan kemudahan untuk membeli produk-produk UMKM yang ada di Kabupaten Purbalingga."

Dari hasil wawancara di atas, dapat dikatakan bahwa program Tuka Tuku memiliki tujuan yang bagus dan sudah cukup berjalan. Masyarakat merasakan kemudahan dengan adanya program Tuka Tuku karena mampu mengenal lebih banyak produk-produk UMKM dan memberikan kemudahan masyarakat untuk membeli produk-produk UMKM melalui online kapan pun dan dimanapun. Dengan semakin dikenalkanya produkproduk UMKM dan meningkatkan penjualan produk lokal, maka akan memberikan dampak yang baik pula untuk peningkatan perokonomian daerah. Dengan demikian, berdasarkan hasil wawancara secara keseluruhan dapat disimpulkan bahwa program Tuka Tuku Purbalingga memiliki tujuan yang baik, dan tujuan tersebut dapat dirasakan manfaatnya oleh pelaku UMKM dan masyarakat, sehingga ada kesesuaian antara tujuan yang sudah direncanakan dengan realisasi tujuan program tersebut.

\section{Pemantauan Program pada Media Pemasaran}

Pemantuan program pada media pemasaran online merupakan kegiatan yang dilakukan setelah program berjalan sehingga dapat menghasilkan informasi apakah program tersebut telah berjalan secara efektif dan berdampak baik pada masyarakat. Terkait pelaksanaan 
pemantauan program disampaikan oleh Bapak Dimas sebagai manajer program Tuka Tuku Purbalingga:

"Terkait pemantauan sendiri dari kami Tuka Tuku setiap bulan melakukan pemantuan dengan pemerintah dan pelaku UMKM yang menjadi mitra Tuka Tuku. Pemantuan dilakukan meliputi penjualan dan hal-hal berkaitan dengan produk UMKM baik penambahan produk ataupun peningkatan kualitas produk yang dapat dikembangkan menjadi produk UMKM yang dapat memasuki akses pasar nasional."

Selain itu, Ibu Yelfi sebagai pemilik usaha Marisa Food yang sudah bergabung dalam program Tuka Tuku menyampaikan bahwa:

"Seringkali pemantauan dilakukan pada saat evaluasi penjualan, pelaku UMKM akan di beri arahan dan dan masukan ketika terjadi masalah dalam pemasukan produksi, terutama ketika belum siap saat diminta untuk memasok hasil produksi. Selain itu pemantuan juga sering dilakukan dengan berdiskusi dengan manajemen dan pengelola program Tuka Tuku Purbalingga."

Dari kedua wawancara tersebut, dapat dikatakan bahwa pemantauan program Tuka Tuku telah dilaksanakana oleh pengelola program bersama dengan pemerintah dan pelaku UMKM, baik dilakukan secara offline ataupun online. Pemantuan dilakukan pengelola program Tuka Tuku untuk menggali informasi terkait apa saja yang menjadi masalah dan penghambat saat pelaku UMKM sedang melakukan produksi. Selain itu, pemantuan juga dilakukan untuk mengetahui stok produk UMKM yang dimiliki oleh pelaku UMKM, dan juga sekaligus melaporkan hasil penjualan. Pelaksanaan pemantauan terhadap ketersediaan dan kualitas produk dibuktikan dari hasil wawancara dengan Ibu Nuri Wahyuni sebagai pengguna program Tuka Tuku:

"Pemantauan program Tuka Tuku terhadap produk-produk UMKM menurut saya sudah dilakukan karena ketersediaan barang di Tuka Tuku yang selalu ada menurut saya menjadi salah satu dari upaya pemantauan produk."

Menurut wawancara tersebut, pemantauan sudah dilakukan, hal ini dibuktikan dengan adanya upaya ketersediaan stok produk-produk UMKM di program Tuka Tuku secara online maupun offline sesuai dengan kebutuhan dan permintaan masyarakat. Dari keseluruhan wawancara dengan narasumber, dapat disimpulkan bahwa telah dilakukan oleh penelola progrm dengan pemerintah dan pelaku UMKM, dimana pemantuan dilaksanakan secara bertahap dan terjadwal, sehingga semua laporan atau 
informasi dapat disampaikan secara detail dan menyeluruh. Laporan atau hasil pemantauan yang telah dilakukan akan digunakan sebagai bahan evaluasi untuk peningkatan program Tuka Tuku Purbalingga, sehingga akan memberikan manfaat yang lebih luas lagi, tidak hanya untuk pelaku UMKM tetapi juga untuk masyarakat di Kabupaten Purbalingga.

\section{KESIMPULAN}

Berdasarkan pembahasan dari hasil penelitian dan analisis mengenai efektivitas program Tuka Tuku Purbalinggga sebagai media pemasaran UMKM di Kabupaten Purbalingga tahun 2019 yang telah dilakukan, maka dapat disimpulkan bahwa program Tuka Tuku Purbalingga sebagai program andalan pemerintah daerah merupakan program yang dirancang dengan tujuan yang sangat bagus. Pemerintah Kabupaten Purbalingga berupaya memberikan fasilitas dan dukungan terhadap keberlangsungan program Tuka Tuku Purbalingga.

Efektifitas program tersebut dinilai dari beberapa indikator, yaitu yang pertama terkait dengan ketepatan sasaran program Tuka Tuku Purbalingga, yang mana program ini sudah menyasar pelaku UMKM di Kabupaten Purbalingga. Namun, perlu adanya peningkatan jumlah UMKM yang tergabung dalam program tersebut, agar semakin banyak UMKM yang dapat merasakan manfaat program Tuka Tuku Purbalingga. Kedua, terkait sosialisasi program Tuka Tuku dapat disimpulkan bahwa sosialisasi sudah dilakukan dengan strategi yang cukup baik, namun perlu ditingkatkan lagi dalam penyampaian informasi program, karena masih banyak masyarakat yang belum menerima informasi terkait program Tuka Tuku secara keseluruhan dan pelaksanaan dari sosialisasi program Tuka Tuku belum dilakukan secara intens atau terus menrus. Ketiga, terkait tujuan program Tuka Tuku dapat disimpulkan bahwa program Tuka Tuku memiliki tujuan yang sangat baik, dan hasil dari pelaksanaan tujuan program Tuka Tuku sudah dapat dirasakan manfaatnya bagi pelaku UMKM dan masyarakat. Terakhir, terkait dengan pemantuan program Tuka Tuku, sudah dilakukan pengawasan oleh pengelola program kepada pelaku UMKM yang sudah bergabung dalam program tersebut, terutama yang berkaitan dengan 
masalah dan hambatan yang dialami pelaku UMKM. Dengan demikian, efektifitas program Tuka Tuku Purbalingga sebagai media pemasaran online Kabupaten Purbalingga dapat dikatakan belum sepenuhnya efektif, karena perlu adanya peningkatan dalam pelaksanaan program Tuka Tuku, terutama berkaitan dengan ketepatan sasaran dan sosialisasi program Tuka Tuku Purbalingga.

\section{DAFTAR PUSTAKA}

Amelia, M. N., Prasetyo, E. Y., \& Maharani, I. (2017). E-UMKM: Aplikasi Pemasaran Produk Umkm Berbasis Android Sebagai Strategi Meningkatkan Perekonomian Indonesia.

Andika. (2019). Omzet Pelaku UMKM Naik Melalui Tuka Tuku Purbalingga. suaramerdeka.com. https://www.suaramerdeka.com.

BPS, (Badan Pusat Statistik). (2019). Jumlah Usaha Menengah, Kecil dan Mikro (UMKM) Menurut Kecamatan di Kabupaten Purbalingga 2019.

Gumilang, G. S. (2016). Metode Penelitian Kualitatif Dalam Bidang Bimbingan Dan Konseling. 2(2), 16.

Hasanah, H. (2017). Teknik-Teknik Observasi (Sebuah Alternatif Metode Pengumpulan Data Kualitatif Ilmu-ilmu Sosial). At-Taqaddum, 8(1), 21.

Indrayani, E. Z., \& Niswah, F. (2017). Efektivitas Program Pengolahan Administrasi Desa Secara Elektronik (PADE) Di Desa Mantup Kecamatan Mantup Kabupaten Lamongan.

Irawan, P. L. T., Kestrilia Rega Prilianti, \& Melany. (2020). Pemberdayaan Usaha Kecil Menengah (UKM) Melalui Implementasi E-commerce di Kelurahan Tlogomas. Jurnal SOLMA, 9(1), 33-44.

J, L., \& M, A. M. (2002). Metodologi Penelitian Kualitatif (17th ed.). PT Remaja Rosdakarya.

Khadafi, \& Mutiarin, D. (2017). Efektivitas Program Bantuan Keuangan Khusus Dalam Mengentaskan Kemiskinan di Kabupaten 
Gunungkidul. Journal of Governance and Public Policy, 4(2).

Murdaningsih, D. (2020). Tuka-Tuku akan Jadi Pilot Project Kemendes. https://www.republika.co.id.

Muzaki, K. (2018). Pemkab Purbalingga Lindungi UMKM dengan Program Bela Beli. tribunnews.com. https://jateng.tribunnews.com.

Putra, T. G. (2015). Peran Pemerintah Daerah Dan Partisipasi Pelaku Usaha Dalam Pengembangan UMKM Manik-Manik Kaca di Kabupaten Jombang. 3(1), 10.

Ryan Rachman. (2019). Diam-Diam, Produk UMKM Purbalingga Sudah GoInternasional. https://www.suaramerdeka.com.

Shadiq, A. N., \& Njatrijani, R. (2016). Implementasi Uu Nomor 7 Tahun 2014 Terhadap Pemberdayaan Usaha Mikro, Kecil Dan Menengah Di Kabupaten Purbalingga Dalam Menghadapimasyarakat Ekonomi Asean. 5(2), 18.

Subandi. (2011). Deskripsi Kualitatif Sebagai Satu Metode Dalam Penelitian Pertunjukan. 11(2).

Suci, Y. R. (2017). Perkembangan UMKM (Usaha Mikro Kecil Dan Menengah) Di Indonesia. 6(1), 8.

Sudaryanto, Ragimun, \& Wijayanti, R. R. (2013). Strategi Pemberdayaan UMKM Menghadapi Pasar Bebas ASEAN. Kementerian Keuangan.

Susanti, M. (2017). Pemanfaatan E-commerce Untuk Mendukung UMKM Dalam Pemasaran. Sistem Informasi dan Teknologi, 1(1), 8.

Wulandari, O. A. D., \& Putri, N. R. (2020). Analisis Pemanfaatan Marketplace Dalam Meningkatkan Pendapatan Bagi Penjualan Produk Umkm Di Purbalingga. Jurnal Ekonomi Manajemen, 6(2), 6.

Yusuf, M. (2014). Metode Penelitian: Kuantitatif, Kualitatif, dan Penelitian Gabungan (1st ed). Kencana. 